\title{
PENGARUH MEDIA SOSIAL BIGO LIVE DAN KEPUASAN DIRI TERHADAP AKTUALISASI DIRI PADA HOST OFFICIAL BIGO LIVE DI JABODETABEK
}

\author{
Herlan Lasmana ${ }^{1 *}$, Lutfiah Arista ${ }^{2}$ \\ ${ }^{1,2}$ Program Studi Ilmu Komunikasi, The London School of Public Relations Jakarta \\ *Penulis korespondensi; Herlanlasmana@gmail.com
}

\begin{abstract}
ABSTRAK
Penelitian ini mengenai pengaruh media sosial Bigo Live dan kepuasan diri terhadap aktualisasi diri. Kehadiran media sosial Bigo Live di kalangan masyarakat menjadi suatu fenomena yang banyak diperbincangkan. Munculnya beberapa motif para host Bigo Live Indonesia dalam menggunakan dan mencari sebuah kepuasan diri terhadap penggunaan aplikasi tersebut, membuat peneliti ingin mengetahui seberapa banyak pengaruh antara penggunaan media sosial Bigo Live dan Kepuasan diri terhadap pembentukan aktualisasi diri para host Bigo Live Indonesia. Tujuan dilakukannya penelitian ini adalah untuk menguji pengaruh langsung masing-masing variabel media sosial Bigo Live dan kepuasan diri terhadap aktualisasi diri, serta menguji pengaruh media sosial Bigo Live bila dikombinasikan dengan kepuasan diri terhadap aktualisasi diri. Teori utama dalam penelitian ini adalah teori model komunikasi SMCR yang dikembangkan oleh David K. Berlo. Model komunikasi Berlo yang dikenal dengan model SMCR yaitu kepanjangan dari Source (sumber), Message (pesan), Channel (Saluran), dan Receiver (penerima). Peneliti ini mengunakan pendekatan kuantitatif, dan teknik analisis data yang digunakan adalah analisis jalur. Sampel dalam penelitian ini adalah Host Official Bigo Live Indonesia yang berdomisili di JABODETABEK yang ditentukan melalui teknik purposive sampling. Hasil penelitian menunjukan bahwa Apabila melihat pada hasil analisis data melalui analisis jalur, ditemukan bahwa terdapat pengaruh langsung dari masing-masing variabel media sosial Bigo Live dan kepuasan diri terhadap aktualisasi diri. Dengan demikian dapat dikatakan variabel media sosial Bigo Live tidak perlu melalui variabel kepuasan diri terlebih dahulu untuk mempengaruhi aktualisasi diri para Host Official Bigo Live, begitu pula sebaliknya. Gabungan dari kedua variabel memiliki pengaruh lebih besar terhadap aktualisasi diri daripada pengaruh langsung dari masing-masing variabel. Hasil regresi linier berganda membuktikan bahwa kepuasan diri mempunyai pengaruh lebih besar daripada media sosial Bigo Live dan hubungan antara media sosial Bigo Live dengan aktualisasi diri melemah atau hilang jika dimasukan variabel kepuasan diri.
\end{abstract}

Kata kunci: Media Sosial, Kepuasan Diri, Aktualisasi Diri, Bigo Live, Model Komunikasi SMCR

\begin{abstract}
This research is about the impact of social media Bigo Live and the self satisfaction towards self actualization. The objective of this study is to examine the direct influence of each social media 'Bigo Live' and the satisfaction towards self actualization, also to examine the influence of the combination between those two variables towards self actualization. The main theory used in this study is the SMCR communication model which was developed by David K. Berlo. This study is a quantitative research and the technique data is path analysis. The samples in this study are official host of Bigo live Indonesia who live in the JABODETABEK area which was determined through a purposive sampling method. The results indicated that social media Bigo Live and self satisfaction each had a direct influence towards self actualization. Furthermore, the mutiple regression analysis result showed that self satisfaction had a bigger influence towards self actualization than media social Bigo live. Therefore, it can be said that the Social Media Bigo Live doesn't need to go through the self-satisfaction to influence the self-actualization of Bigo Live Official Hosts and vice versa. The combination of the two variables has a greater influence on self-actualization than the direct influence of each variable. The results of multiple linear regression prove that self satisfaction has a greater influence than social media Bigo Live and the relationship between social media Bigo Live with self-actualization is weakened or lost if the variable self-satisfaction is included.
\end{abstract}

Keywords: Social Media, Self Satisfaction, Self Actualization, Bigo Live, SMCR Communication Model.

\section{PENDAHULUAN}

Terjadi perkembangan media sosial mengakibatkan perubahan perilaku manusia yang bergantung terhadap penggunaan media sosial dalam kehidupan sehari-hari. Teknologi saat ini membantu mempermudah segala kegiatan manusia untuk tetap terhubung dengan setiap orang. Media sosial sepertinya sudah menjadi tren tersendiri di kalangan masyarakat saat ini dan seolah tidak lagi dapat dipisahkan dari kehidupan manusia.

Pesatnya perkembangan teknologi informasi membuat pengguna internet kawasan Asia tumbuh pesat 1.319 persen sepanjang 2000-2015. Menurut data Internet World Stats, pengguna internet Asia saat ini 
mencapai 1,62 miliar jiwa dengan penetrasi 40,2 persen dari total populasi sebesar 4 miliar jiwa. Sebanyak 674 juta jiwa pengguna internet Asia berasal dari Cina. Indonesia meraih peringkat ke empat dengan jumlah 78 juta jiwa pengguna internet (Hatriani, 2016, Januari 13).

Teknologi komunikasi tak berhenti hanya sampai pesan singkat semata. Inovasinya terus berkembang pada media live streaming yang kini bisa menjadi pilihan saat berinteraksi antar pengguna internet. Teknologi streaming merupakan teknologi yang digunakan untuk memainkan audio file dan video file secara langsung ataupun rekaman melalui web server. Salah satu layanan yang mendukung tren live streaming show saat ini adalah Clip on Yu, Periscope, Nono Live, dan Bigo Live (Afrian, 2015, Agustus 20).

Layaknya media sosial berbasis video live streaming yang disebutkan di atas merupakan beberapa aplikasi yang saat ini menyediakan tayangan video secara live. "Bigo Live merupakan aplikasi sosial media streaming video secara langsung melalui ponsel. Semenjak diluncurkan pada bulan Maret 2016, Bigo Live menjadi sangat popular di seluruh dunia dan langsung menjadi aplikasi yang meraih peringkat pertama di Apple App Store Thailand dan Vietnam. Peluncuran Bigo Live di Indonesia diharapkan dapat menyalurkan bakat penggunanya untuk berbagi hobi, bakat dan keahlian kepada semua orang. Bigo Live menggunakan platform streaming mobile, sehingga siapapun, dimanapun dan kapanpun dapat melakukan live video". (Rilisiana, 2016, Juli 12).

Aplikasi Bigo Live menjadi media sosial yang sukses menempati urutan pertama aplikasi mobile video streaming, di Google App Store Bigo Live menempati urutan ketiga dan iOs App Store menempati urutan pertama. Pengguna Bigo Live di Indonesia pada tahun 2016 berjumlah 10 juta pengguna dan pengguna yang aktif berjumlah 5 juta pengguna. Siaran yang dilakukan oleh pengguna Bigo Live sekisar 150.000 siaran perharinya (B.Rizal, wawancara prariset, 6 November 2016).

Berbagai macam fasilitas yang ditawarkan oleh media sosial Bigo Live membuat para pengguna merasa bebas untuk berbagi pengalaman- pengalamannya dalam fitur Bigo Live, sebagian pengguna merasa senang ketika melihat dirinya mampu menampilkan beberapa konten kemampuan dari penyiarnya seperti menyanyi, tutorial make up, fashion show, tutorial memasak, kuliner, hingga memberikan konten ngajar- mengajar pelajaran sekolah. Hal ini memungkinkan orang-orang yang menggunakan Bigo Live dapat terbantu mencapai aktualisasi dirinya melalui media tersebut (B.Rizal, wawancara pra-riset, 6 November 2016).

Menurut Hersinta dan Soepomo dalam Communicare Journal of Communication Studies Vol. V No. 1 (2011, p. 5) Aktualisasi diri adalah sebuah keadaan dimana seorang manusia telah merasa menjadi dirinya sendiri, mengerjakan sesuatu yang disukainya dengan gembira, dengan hati ikhlas. Ia tidak lagi menempatkan keberhasilan dari pekerjaannya pada ukuran yang biasanya berlaku, yakni penghasilan yang diperoleh dari hasil sebuah kerja. Ukurannya menjadi berubah sesuai dengan nilai-nilai kehidupan yang dianut dan difahami oleh dirinya. Dalam teori Kebutuhan Maslow, konsep aktualisasi diri didefinisikan sebagai keinginan untuk mewujudkan kemampuan diri atau "keinginan untuk menjadi apapun yang seseorang mampu untuk mencapainya."

Orang berkomunikasi untuk menunjukkan dirinya eksis. Inilah yang disebut aktualisasi diri atau lebih tepat lagi pernyataan eksistensi diri. Kita dapat memodifikasi frase filosof Prancis Rene Dercastes (1596-1650) yang terkenal itu Cogito Ergo Sum ("Saya berpikir, maka saya ada") menjadi "Saya berbicara, maka saya ada". Bila kita berdiam diri, orang lain akan memperlakukan kita seolah-olah kita tidak eksis. Namun ketika kita berbicara, kita sebenarnya menyatakan bahwa kita ada (Mulyana, 2009, p.14).

Hal yang dilakukan dalam ajang eksistensi diri di sosial media diantaranya mem-posting hal-hal yang menceritakan kehidupan penggunanya. Seperti yang dikutip oleh (Setiawan, 2015, Mei 15) dalam Kompas.com, hal-hal yang terkait dalam melakukan eksistensi diri diantaranya "Mengunggah segala aktivitas yang dilakukan, mengumbar kemesraan suatu hubungan, mengumbar drama kehidupan, mengeluh tentang pekerjaan, banyaknya mengunggah foto selfie dan lainnya". Dengan tujuan apa yang kita ingin lakukan dapat dikenal sebagai siapa di kalangan orang banyak.

Teknologi telah memfasilitasi kebutuhan orang untuk narsis dan memudahkan orang untuk eksis," kata Roslina Verauli, psikolog anak remaja dan keluarga. Menurutnya kini semakin mudah orang dengan hobi tertentu memasang foto atau video hasil karya mereka agar bisa dinikmati pula oleh orang lain di media sosial yang dikutip dari website CNNIndonesia.com (Windratie, 2015, Januari 7). 
Yang dikutip dari Jurnal E-Komunikasi (Telengkeng, 2014 , p. 1) munculnya motif ini dikarenakan keinginan orang-orang untuk melakukan sesuatu yang ingin mencari kepuasan tersendiri dari dalam dirinya. Jika seseorang hanya berdiam saja tanpa melakukan apapun, maka tidak dapat dikatakan motif. Motif adalah kepuasan yang dicari seseorang dalam menggunakan media tertentu (McQuail, 1997:74).

Berbicara mengenai rewards berupa gift yang dapat ditukarkan dengan uang merupakan salah satu motif para host Bigo Live untuk melakukan siaran. Seperti dikutip dari Kaskus, semakin banyak orang yang datang ke Channel Broadcast kita dan memberi Gift (istilah pemberian hadiah melalui icon) maka akan semakin banyak diamond terkumpul. Pada akhirnya nanti diamond ini bisa ditukarkan menjadi uang cash, minimal penarikan adalah 6.700 diamond atau setara dengan $\mathrm{Rp} 2.000 .000$. Dengan adanya fitur penukaran diamond menjadi uang cash inilah yang menyebabkan banyak para broadcaster rela melakukan hal-hal unik dan terkadang melampaui batas, yaitu dengan menunjukan bagian intim mereka.Tujuannya, tentu saja jika diamond sudah terkumpul banyak maka akan mereka tukarkan menjadi uang, dikutip dari website Tribunnews.com (Sugiyarto, 2016, Agustus 27).

Kini Bigo Live diminati berbagai kalangan pengguna, mulai para remaja sampai orang lanjut usia kini sudah banyak yang menggunakan media sosial ini. Pengguna juga datang dari berbagai latar belakang profesi seperti artis, model, wartawan, pengusaha, mahasiswa, siswa, guru, dosen, tentara, polisi, dan banyak lagi. Banyak pengguna yang sudah mendapatkan keuntungan positif dari Bigo Live, mulai dari kebutuhan informasi yang terpenuhi hingga memperoleh keuntungan ekonomi dari Bigo Live, dikutip dari media online Bagitu.com yang berjudul Live, Medsos Berbasis Siaran Langsung Kian Digemari (Manua, 2016 Desember 7).

Kehadiran media sosial Bigo Live di kalangan masyarakat menjadi suatu fenomena yang banyak diperbincangkan. Munculnya beberapa motif para host Bigo Live Indonesia dalam menggunakan dan mencari sebuah kepuasan diri terhadap penggunaan aplikasi tersebut, membuat peneliti ingin mengetahui seberapa banyak pengaruh antara penggunaan media sosial Bigo Live dan Kepuasan diri terhadap pembentukan aktualisasi diri para host Bigo Live Indonesia. Menurut latar belakang diatas membuat peneliti ingin menguji adakah pengaruh media sosial Bigo Live dan kepuasan diri terhadap aktualisasi diri. Atau apakah ada pengaruh kombinasi diantara variable pertama media sosial Bigo Live dan variable kedua kepuasan diri terhadap aktualisasi dirii.

\section{LITERATUR DAN METODOLOGI}

\subsection{Model Komunikasi Berlo}

Sebagaimana dikemukakan Berlo dalam buku Ilmu Komunikasi Suatu Pengantar (Mulyana, 2009, p.162163), Sumber (Source) adalah pihak yang menciptakan pesan, baik seseorang ataupun suatu kelompok. Pesan (Message) adalah terjemahan gagasan ke dalam kode simbolik, seperti bahasa atau isyarat. Saluran (Channel) adalah medium yang membawa pesan dan penerima (Receiver) adalah orang yang menjadi sasaran komunikasi.

Dalam penelitian ini, terkait dengan komunikasi Berlo yaitu bahwa Sumber (Source) adalah para penyiar Official Host Bigo Live Indonesia yang memberikan Pesan (Message) berupa siaran langsung, yang di komunikasikan melalui Saluran (Channel) yaitu media sosial Bigo Live, yang ditunjukkan kepada Penerima (Receiver) adalah penonton siaran Bigo Live.

Berlo juga menggambarkan kebutuhan penyandi (encoder) dan penyandi-balik (decoder) dalam proses komunikasi. Enkoder bertanggung jawab mengekspresikan maksud sumber dalam bentuk pesan dan dekoder untuk menerjemahkan pesan yang diterima dalam kebanyakan kasus, penyandi balik adalah perangkat keterampilan indrawi penerima (Mulyana, 2009, p.162).

Menurut model Berlo, sumber dan penerima pesan dipengaruhi oleh faktor-faktor: keterampilan komunikasi, sikap, pengetahuan, sistem sosial, dan budaya. Pesan dikembangkan berdasarkan elemen, struktur, isi, perlakuan, dan kode. Salurannya berhubungan dengan panca indra: melihat, mendengar, menyentuh, membaui, dan merasai (mencicipi). Model ini lebih bersifat organisasional daripada mendeskripsikan proses karena tidak menjelaskan umpan balik (Mulyana, 2009, p.162-163).

Salah satu kelebihan model Berlo adalah bahwa model ini tidak terbatas pada komunikasi publik atau komunikasi massa, namun juga komunikasi antar pribadi dan berbagai bentuk komunikasi tertulis. Model Berlo juga bersifat heuristik (merangsang penelitian), karena merinci unsur-unsur yang penting dalam proses komunikasi. Model ini misalnya dapat memandu Anda untuk meneliti efek keterampilan 
komunikasi penerima atas penerimaan pesan yang Anda kirimkan kepadanya atau Anda sebagai pembicara mungkin mulai menyadari bahwa latar belakang sosial Anda mempengaruhi sikap penerima pesan Anda (Mulyana, 2009, p.163-164).

Khusus mengenai istilah Channel yang disingkat $\mathrm{C}$ pada rumus S-M-C-R itu yang berarti saluran atau media, komponen tersebut menurut Edwar Sappir mengandung dua pengertian, yakni primer dan sekunder. Media sebagai saluran primer adalah lambang, misalnya bahasa, kial (gesture), gambar atau warna, yaitu lambang-lambang yang dipergunakan khusus dalam komunikasi tatap muka (face-to-face communication), sedangkan media sekunder adalah media yang berwujud, baik media masa, misalnya surat kabar, televisi atau radio, maupun media nirmassa, misalnya, surat, telepon, atau poster (Effendy, 2003, p. 256).

\subsection{Computer Mediated Communication (CMC)}

Dengan berkembangnya teknologi sebagai media komunikasi antar individu, yang dihubungkan oleh jaringan internet dan biasanya disebut Computer Mediated Communication. Menurut John December (1997) dalam buku Computer Mediated Communication: Social Interaction And The Internet (Thurlow, Lengel dan Tomic, 2007, p.15), CMC adalah proses komunikasi manusia melalui komputer, melibatkan orang dan terletak dalam konteks khusus, terlibat dalam proses untuk membentuk media untuk berbagai tujuan.

Pengertian lainnya menurut Susan Hearing (1996) dalam buku Computer Mediated Communication: Social Interaction and The Internet $\mathrm{CMC}$ adalah komunikasi yang terjadi antara manusia melalui perantara komputer (Thurlow, Lengel dan Tomic, 2007, p.15).

\subsection{Teori Social Presence}

Kehadiran sosial adalah berkomunikasi menggunakan tanda visual seperti ekspresi wajah, gerakan dan kontak mata (Thurlow, Lengel dan Tomic, 2007, p. 48).

\subsection{New Media}

Pada buku Littlejohn dijelaskan bahwa pada tahun 1990, Mark Poster meluncurkan bukunya yang berjudul "The Second Media Age" yang menandai periode baru dimana teknologi interaktif dan komunikasi jaringan, khususnya dunia maya akan mengubah masyarakat (Littlejohn, 2009, p. 413).

\subsection{Internet}

Internet juga menyediakan media untuk berkomunikasi secara langsung (realtime) melalui teks dengan fasilitas chatting, bahkan sebagian layanan memungkinkan komunikasi suara (voice) di ruang chatting (chatt room) (Rasul, 2008, p.4-5).

\subsection{Definisi Media Sosial}

Media sosial mengacu pada aktivitas, praktis, dan kegiatan di dunia maya dalam suatu komunitas sekelompok orang yang terkumpul untuk berbagi informasi, pengetahuan dan opini menggunakan Conversational Media (Safko \& Brake, 2009, p.6).

\subsection{Karakteristik Media Sosial}

Dikutip dari Jurnal Khasanah Ilmu (Pradiatiningtyas, 2016, p.3) menurut Purnama, 2011:116 media sosial mempunyai beberapa karakteristik khusus diantaranya:

1. Jangkauan (reach): daya jangkauan social media dari skala kecil hingga khalayak global.

2. Aksesibilitas (accessibility): social media lebih mudah diakses oleh publik dengan biaya yang terjangkau.

3. Penggunaan (usability): social media relatif mudah digunakan karena tidak memerlukan keterampilan dan pelatihan khusus.

4. Aktualitas (immediacy): social media dapat memancing respon khalayak lebih cepat.

5. Tetap (permanence): social media dapat menggantikan komentar secara instan atau mudah melakukan proses pengeditan.

\subsection{Live Streaming / Live Casting}

Menurut Safko \& Brake dalam bukunya berjudul The Social Media Bible : Tactics, Tools, \& Strategies For Business Succes (2009, p.29) live casting merupakan kategori yang meliputi radio internet dan aplikasi lain yang memungkinkan Anda untuk live streaming siaran kepada audiens atau jejaring sosial. Live casting menawarkan cara yang fleksible untuk terlibat kepada audiens dengan memberikan konten yang mendidik atau menghibur

\subsection{Teori Kegunaan dan Gratifikasi (Uses and Gratification)}

Teori ini menyatakan bahwa orang secara efektif mencari media tertentu dan muatan (isi) tertentu untuk menghasilkan kepuasaan (atau hasil) tertentu (West dan Turner, 2008, p. 101). 
Teori Kegunaan dan Gratifikasi adalah perluasan dari teori kebutuhan dan motivasi (Maslow, 1970). Dalam teori kebutuhan dan motivasi, Abraham Maslow menyatakan bahwa orang secara aktif berusaha untuk memenuhi hierarki kebutuhannya. Setelah mereka memperoleh tujuan yang mereka cari pada satu tingkat hierarki, mereka dapat bergerak ke tahap berikutnya (West dan Turner, 2008, p.101).

Tabel 1. Kebutuhan Yang Dipuaskan Oleh Media

\begin{tabular}{|c|c|c|}
\hline Tipe Kebutuhan & Deskripsi & Contoh Media \\
\hline Kognitif & $\begin{array}{l}\text { Memperoleh } \\
\text { informasi, } \\
\text { pengetahuan, } \\
\text { pemahaman }\end{array}$ & $\begin{array}{l}\text { Televisi (berita), } \\
\text { video ("Bagaimana } \\
\text { Memasang Lantai } \\
\text { Keramik"), film } \\
\text { (dokumenter atau } \\
\text { film berdasarkan } \\
\text { sejarah, misalnya } \\
\text { Cinderella Man) }\end{array}$ \\
\hline Afektif & $\begin{array}{l}\text { Pengalaman } \\
\text { emosional, } \\
\text { menyenangkan, } \\
\text { atau estetis }\end{array}$ & $\begin{array}{l}\text { Film, televisi } \\
\text { (komedi situasi, } \\
\text { opera sabun) }\end{array}$ \\
\hline Integrasi personal & $\begin{array}{l}\text { Meningkatkan } \\
\text { kredibilitas, percaya } \\
\text { diri, dan status }\end{array}$ & $\begin{array}{l}\text { Video ("Berbicara } \\
\text { dengan Keyakinan") }\end{array}$ \\
\hline Integrasi sosial & $\begin{array}{l}\text { Meningkatkan } \\
\text { hubungan dengan } \\
\text { keluarga, teman, } \\
\text { dan lainnya }\end{array}$ & $\begin{array}{l}\text { Internet (e-mail, chat } \\
\text { room, Listerv, IM) }\end{array}$ \\
\hline $\begin{array}{l}\text { Pelepasan } \\
\text { ketegangan }\end{array}$ & $\begin{array}{l}\text { Pelarian dan } \\
\text { pengalihan }\end{array}$ & $\begin{array}{l}\text { Televisi, film, video, } \\
\text { radio, Internet }\end{array}$ \\
\hline
\end{tabular}

Sumber: Diadaptasi dari Katz Gurevitch, \& Haas, 1973 West dan Turner, 2008, p.105.

Menurut Effendy (2003, p.294) penjelasan dari beberapa tipe kebutuhan individual dikategorikan sebagai berikut:

1) Cognitive needs (Kebutuhan kognitif):

Kebutuhan yang berkaitan dengan peneguhan informasi, pengetahuan dan pemahaman mengenai lingkungan. Kebutuhan ini didasarkan pada hasrat untuk memahami dan menguasai lingkungan, juga memuaskan rasa penasaran kita dan dorongan untuk penyelidikan kita.

2) Affective needs (Kebutuhan Afektif):

Kebutuhan yang berkaitan dengan peneguhan pengalaman-pengalaman yang estetis, menyenangkan, dan emosional.

3) Personal integrative needs (Kebutuhan pribadi secara integratif):

Kebutuhan yang berkaitan dengan peneguhan kredibilitas, kepercayaan, stabilitas, dan status individual. Hal-hal tersebut diperoleh dari hasrat akan harga diri.
4) Social integrative needs (Kebutuhan sosial secara integratif):

Kebutuhan yang berkaitan dengan peneguhan kontak dengan keluarga, teman, dan dunia. Halhal tersebut didasarkan pada hasrat untuk berafiliasi.

5) Escapist needs (Kebutuhan pelepasan):

Kebutuhan yang berkaitan dengan upaya menghindarkan tekanan, ketegangan, dan hasrat akan keanekaragaman.

\subsection{Kepuasan Diri}

Kepuasan bisa diartikan sebagai "upaya pemenuhan sesuatu" atau "membuat sesuatu memadai". Oxford Advanced Learner's Dictionary (2000) mendeskripsikan kepuasan sebagai "the good feeling that you have when you achieved something or when something that you wanted to happen does happen" perasaan senang yang dimiliki oleh seseorang ketika seseorang mendapatkan sesuatu atau sesuatu yang diinginkan dapat tercapai (Tjiptono dan Chandra, 2005, p.195).

\subsection{Aktualisasi Diri}

Orang berkomunikasi untuk menunjukkan dirinya eksis. Inilah yang disebut aktualisasi diri atau lebih tepat lagi pernyataan eksistensi diri. Kita dapat memodifikasi frase filosof Prancis Rene Dercastes (1596-1650) yang terkenal itu Cogito Ergo Sum ("Saya berpikir, maka saya ada") menjadi "Saya berbicara, maka saya ada". Bila kita berdiam diri, orang lain akan memperlakukan kita seolah-olah kita tidak eksis. Namun ketika kita berbicara, kita sebenarnya menyatakan bahwa kita ada (Mulyana, 2009, p.14).

Kebutuhan aktualisasi diri adalah kebutuhan seseorang untuk mampu menjadi apa yang diinginkan sesuai dengan potensi yang dimiliki. Misalnya seorang musician harus bermain musik, seorang profesor harus mengajar, dan sebagainya. Maslow mengatakan bahwa "What a man can be, he must be" (Robbins dan Coulter, 2010, p.110).

Menurut Rogers aktualisasi diri merupakan proses menjadi diri sendiri dan mengembangkan sifat-sifat dan potensi-potensi psikologis yang unik (Hambali \& Jaenudin, 2013, p.189).

\subsection{Indikator-Indikator Aktualisasi Diri}

Menurut Robbins dan Coulter (2010, p.110) menyebutkan indikator kebutuhan aktualisasi diri adalah sebagai berikut: 
1. Kebutuhan pertumbuhan (growth need) Kebutuhan pertumbuhan adalah kebutuhan untuk mengetahui dan memahami sesuatu, untuk tumbuh dan berkembang dengan dihargai orang lain.

2. Kebutuhan pencapaian potensi seseorang (achieving one'spotential)

Yaitu kebutuhan seseorang untuk mengembangkan potensi, kemampuan, dan bakat yang ada dalam dirinya secara maksimal.

3. Kebutuhan pemenuhan diri (self-fulfillment) Yaitu kebutuhan untuk memenuhi keberadaan diri dengan memaksimalkan penggunaan kemampuan dan potensi yang ada dalam dirinya.

4. Kebutuhan dorongan

Yaitu dorongan dalam diri individu untuk mempertahankan keberadaan dirinya sesuai dengan potensi yang dimilikinya.

\subsection{Metode Penelitian}

Metode penelitian menurut Sugiyono (2012, p.3) adalah cara ilmiah untuk mendapatkan data dengan tujuan dan kegunaan tertentu. Metode penelitian ini menggunakan metode kuantitatif jenis penelitian eksplanatif. Yang sudah dirangkum dari buku Metode Penelitian Kombinasi (Sugiyono, 2012, p.11) metode kuantitatif diartikan sebagai metode penelitian yang berlandaskan pada filsafat positivisme, digunakan untuk meneliti pada populasi atau sampel tertentu, pengumpulan data menggunakan instrument penelitian, analisis data bersifat kuantitatif atau statistik, dengan tujuan untuk menguji hipotesis yang telah ditetapkan.

Riset kuantitatif adalah riset yang menggambarkan atau menjelaskan suatu masalah yang hasilnya dapat digeneralisasikan. Dengan demikian tidak terlalu mementingkan kedalaman data atau analisis. Periset lebih mementingkan aspek keluasan data sehingga data atau hasil riset dianggap merupakan representasi dari seluruh populasi (Kriyantono, 2014, p.55).

\subsection{Populasi dan Sampel}

Untuk keperluan penelitian ini, populasi adalah keseluruhan gejala satuan yang ingin diteliti (Prasetyo dan Jannah, 2008, p.119). Populasi yang digunakan dalam penelitian ini adalah pengguna media sosial Bigo Live dan mengikuti segala aktivitas dalam aplikasi Bigo Live. Oleh karena itu, peneliti akan mengambil populasi dari Official Host Bigo Live Indonesia sejumlah 1082 dari data yang didapatkan oleh Officer Bigo Live Indonesia.

Sampel adalah bagian dari populasi yang ingin diteliti. Menurut Bailey, (1994, p. 83) dalam buku
(Prasetyo dan Jannah, 2008, p.119) sampel harus dilihat sebagai suatu pendugaan terhadap populasi dan bukan populasi itu sendiri.

Nonprobability Sampling adalah teknik pengambilan sampel yang tidak memberi peluang/kesempatan sama bagi setiap unsur atau anggota populasi untuk dipilih menjadi sampel. Sampling yang dipakai dalam penelitian ini adalah sampling purposive yang menjelaskan bahwa teknik penentuan sampel dengan pertimbangan tertentu (Sugiyono, 2013, p.84-85). Menurut Siregar dalam buku Metode Penelitian Kuantitatif, purposive sampling merupakan metode penetapan responden untuk dijadikan sampel berdasarkan pada kriteria-kriteria tertentu (Siregar, 2013, p. 33).

Sampel yang digunakan dalam penelitian ini adalah kelompok Official Host Bigo Live Indonesia yang berdomisili di jabodetabek menggunakan aplikasi media sosial Bigo Live. Penelitian ini, dimaksudkan untuk membuktikan adakah pengaruh antara penggunaan media sosial Bigo Live dan kepuasan diri terhadap aktualisasi diri pada Official Host Bigo Live Indonesia di Jabodetabek.

Alasan-alasan yang menjadi pertimbangan penulis dalam penentuan sampel ialah:

- Seluruh responden merupakan Official Host Bigo Live Indonesia.

- Seluruh responden berdomisili di Jabodetabek (Jakarta, Bogor, Depok, Tanggerang, Bekasi).

\section{HASIL DAN PEMBAHASAN}

\subsection{Analisis Uji Jalur}

Tabel 2. Analisis Jalur

\begin{tabular}{cccc}
\hline & $\mathbf{X 1}$ & $\mathbf{X 2}$ & $\mathbf{Y}$ \\
\hline $\mathbf{X 1}$ & 1 & 0,683 & 0,596 \\
$\mathbf{X} 2$ & 0,683 & 1 & 0,832 \\
$\mathbf{Y}$ & 0,596 & 0,832 & 1 \\
\hline
\end{tabular}

Sumber: Data Primer, 2017

Berdasarkan tabel di atas dapat diketahui bahwa:

1. Hubungan antara variabel $\mathrm{X} 1$ dan $\mathrm{Y}$ adalah sebesar 0,596

2. Hubungan antara variabel X1 dan X2 adalah sebesar 0,683

3. Hubungan antara variabel $\mathrm{X} 2$ dan $\mathrm{Y}$ adalah sebesar 0,832

Berdasarkan tabel matriks korelasi antar variabel, maka diketahui kontribusi sebagai berikut: 
Kontribusi X1 (Media sosial Bigo Live) terhadap Y (Aktualisasi Diri)

1. Kontribusi langsung $=0,596 \times 0,596=0,355=$ $35,5 \%$

2. Kontribusi melalui hubungan korelatif dengan $\mathrm{X} 2$ $=0,596 \times 0,683 \times 0,832=0,337=33,7 \%$

Kontribusi X1 (Media sosial Bigo Live) terhadap X2 (Kepuasan Diri)

1. Kontribusi langsung $=0,683 \times 0,683=0,466=$ $46,6 \%$

2. Kontribusi melalui hubungan korelatif dengan $\mathrm{Y}=$ $0,683 \times 0,596 \times 0,832=0,337=33,7 \%$

Kontribusi X2 (Kepuasan Diri) terhadap Y (Aktualisasi Diri)

1. Kontribusi langsung $=0,832 \times 0,832=0,692=$ $69,2 \%$

2. Kontribusi melalui hubungan korelatif dengan $X 1$ $=0,832 \times 0,683 \times 0,596=0,337=33,7 \%$

Berdasarkan hasil uji jalur diketahui bahwa variabel X1 memiliki pengaruh langsung terhadap Y. Hal ini terlihat dari nilai kontribusi langsung X1 terhadap Y lebih besar daripada kontribusi melalui hubungan korelatif dengan X2. Kemudian diketahui pula bahwa variabel X2 memiliki pengaruh langsung terhadap Y. Hal ini terlihat dari nilai kontribusi langsung $\mathrm{X} 2$ terhadap Y lebih besar daripada kontribusi melalui hubungan korelatif dengan X1.

Terlihat pada hasil di atas dapat dikatakan bahwa kontribusi variabel X2 terhadap Y lebih besar dibandingkan dengan kontribusi yang diberikan oleh variabel X1 terhadap Y. Dengan demikian, dapat diduga bahwa X2 memiliki pengaruh yang lebih besar.

\subsection{Analisis Korelasi}

Tabel 3. Hasil Analisis Korelasi

\begin{tabular}{llrrr}
\multicolumn{4}{c}{ Correlations } \\
\hline & & Total. & Total. \\
X1 & Total. \\
& & \multicolumn{1}{c}{ Y } \\
\hline Total.X1 & Pearson Correlation & 1 &, $683^{* *}$ & \multicolumn{1}{c}{, $596^{* *}$} \\
& Sig. (2-tailed) & &, 000 &, 000 \\
& N & 91 & 91 & 91 \\
\hline Total.X2 & Pearson Correlation &, $683^{* *}$ & 1 &, $832^{* *}$ \\
& Sig. (2-tailed) &, 000 & &, 000 \\
& N & 91 & 91 & 91 \\
\hline Total.Y & Pearson Correlation &, $596^{* *}$ &, $832^{* *}$ & 1 \\
& Sig. (2-tailed) &, 000 &, 000 & \\
& N & 91 & 91 & 91 \\
\hline
\end{tabular}

** Correlation is significant at the 0.01 level (2-tailed).

Sumber: Data Primer, 2017

Dilihat dari hasil uji korelasi antara X1 (Media Sosial Bigo Live) dan X2 (Kepuasan Diri) terhadap Y (Aktualisasi Diri) dapat disimpulkan bahwa:
X1 (Media Sosial Bigo Live) terhadap Y (Aktualisasi diri)

Variabel $\mathrm{X} 1$ memiliki hubungan dengan $\mathrm{Y}$ yang dilihat dari nilai signifikansi 0,000 lebih kecil daripada 0,05 . Dapat dilihat juga pada tabel yang memiliki tanda bintang dengan nilai koefisien korelasi pearson yang mencapai 0,596 .

Hal ini berarti terdapat hubungan antara media sosial Bigo Live terhadap aktualisasi diri sifatnya kuat dan berarti variabel $\mathrm{X} 1$ dan variabel $\mathrm{Y}$ signifikan.

X1 (Media Sosial Bigo Live) terhadap X2 (Kepuasan diri)

Variabel X1 memiliki hubungan dengan X2 yang dilihat dari nilai signifikansi 0,000 lebih kecil daripada 0,05 . Dapat dilihat juga pada tabel yang memiliki tanda bintang dengan nilai koefisien korelasi pearson yang mencapai 0,683 .

Hal ini berarti terdapat hubungan antara media sosial Bigo Live terhadap kepuasan diri sifatnya kuat dan berarti variabel X1 dan variabel X2 signifikan.

\section{X2 (Kepuasan Diri) terhadap Y (Aktualisasi diri)}

Variabel X2 memiliki hubungan dengan Y yang dilihat dari nilai signifikansi 0,000 lebih kecil daripada 0,05 . Dapat dilihat juga pada tabel yang memiliki tanda bintang dengan nilai koefisien korelasi pearson yang mencapai 0,832 .

Hal ini berarti terdapat hubungan antara kepuasan diri terhadap aktualisasi diri sifatnya kuat dan berarti variabel X2 dan variabel Y signifikan.

\subsection{Analisis Regresi Linier Berganda}

Analisis pada penelitian ini digunakan untuk mengukur pengaruh variabel bebas terhadap variabel terikat.

Tabel 4. Koefisien Penentu

\begin{tabular}{|c|c|c|c|c|}
\hline Model & $\mathbf{R}$ & R Square & $\begin{array}{l}\text { Adjusted } \\
\text { R Square }\end{array}$ & $\begin{array}{l}\text { Std. Error of } \\
\text { the Estimate }\end{array}$ \\
\hline 1 &, $833^{\mathrm{a}}$ & ,693 &, 686 & 4,496 \\
\hline
\end{tabular}

Sumber Data: Data Primer, 2017

Pada tabel Summary, dapat dilihat bahwa didapatkan hasil $\mathrm{R}$ square sebesar 0,693 atau sama dengan Koefisien Penentu $(K P)=69,3 \%$. Hal ini berarti gabungan nilai kontribusi dari X1 dan X2 lebih besar terhadap $\mathrm{Y}$ dibandingkan dengan nilai kontribusi langsung dari masing-masing variabel. 
Dengan demikian, dapat disimpulkan bahwa gabungan dari X1 (Media sosial Bigo Live) dan X2 (Kepuasan diri) memiliki pengaruh lebih besar terhadap $\mathrm{Y}$ (Aktualisasi diri) dibandingkan dengan pengaruh dari masing-masing variabel.

Besaran nilai $r$ square merupakan salah satu kriteria dalam menentukan bahwa variabel bebas yang dipilih dapat dengan tepat menjelaskan variabel terikat. Nilai $\mathrm{r}$ square sebesar 0,693 menunjukkan bahwa variasi dari variabel $\mathrm{X}$ dapat dijelaskan dengan variabel $\mathrm{Y}$ sebesar $69,3 \%$, sedangkan 30,7\% dijelaskan oleh faktor-faktor lain:

- $\mathrm{KP}=\mathrm{r}^{2} \times 100 \%$

- KP=0,693 x 100\%

- KP=69,3\%

Hal ini berarti kedua variabel X1 (Media sosial Bigo Live) dan X2 (Kepuasan diri) mempengaruhi Y (Aktualisasi diri) sebesar 69,3\% dan sisanya 30,7\% dipengaruhi oleh faktor-faktor lain yang tidak diteliti dalam model ini.

Tabel 5. Regresi Linier Berganda

\begin{tabular}{|c|c|c|c|c|c|c|}
\hline & \multirow[t]{2}{*}{ Model } & \multicolumn{3}{|c|}{$\begin{array}{lc}\text { dardized } & \text { Standardi } \\
\text { icients } & \text { zed } \\
& \begin{array}{c}\text { Coefficie } \\
\text { nts }\end{array} \\
\end{array}$} & \multirow[t]{2}{*}{$\mathrm{T}$} & \multirow[t]{2}{*}{ Sig. } \\
\hline & & B & Std. Error & Beta & & \\
\hline & (Constant) & ,482 & 3,987 & & ,121 & ,904 \\
\hline & Total.X1 & ,060 & ,091 & 053 & 657 & ,513 \\
\hline & Total.X2 &, 896 & ,091 & ,796 & 9,851 &, 000 \\
\hline
\end{tabular}

a. Dependent Variable: Total.Y

Sumber: Data Primer, 2017

\subsection{Pengujian pengaruh Media Sosial Bigo Live (X1) terhadap Aktualisasi Diri (Y)}

Dari hasil tabel di atas terlihat bahwa besarnya nilai $\mathrm{t}$ variabel X1 terhadap Y adalah 0,657 dengan nilai signifikansi 0,513 yang lebih besar dari 0,05. Maka dari itu, secara parsial variabel X1 tidak berpengaruh terhadap Y. Hal ini juga membuktikan bahwa Ha1 ditolak Ho1 diterima, yaitu tidak ada pengaruh langsung dari penggunaan media sosial Bigo Live terhadap aktualisasi diri.

\subsection{Pengujian pengaruh Kepuasan Diri (X2) terhadap Aktualisasi Diri (Y)}

Dari hasil tabel di atas menunjukkan bahwa besarnya nilai $\mathrm{t}$ variabel $\mathrm{X} 2$ terhadap $\mathrm{Y}$ pada kolom beta adalah 9,851 dengan nilai signifikansi 0,000 yang lebih kecil dari 0,05. Maka dari itu, secara parsial variabel X1 memiliki pengaruh terhadap Y. Hal ini juga membuktikan bahwa $\mathrm{Ha} 2$ diterima, yaitu ada pengaruh langsung dari kepuasan diri terhadap aktualisasi diri.

Secara uji hipotesis, terbukti bahwa X1 tidak memiliki pengaruh terhadap $\mathrm{Y}$ dan $\mathrm{X} 2$ memiliki pengaruh terhadap Y. Selain itu dalam hal ini, sesuai dengan yang terlihat pada nilai $\mathrm{T}$ bahwa nilai $\mathrm{T} X 2$ lebih besar dari nilai X1. Dengan demikian, dapat disimpulkan bahwa X2 (kepuasan diri) mempunyai pengaruh lebih besar terhadap Y (aktualisasi diri) dibandingkan dengan X1 (media sosial Bigo Live).

\subsection{Kaitan Hasil Penelitian dengan Teori}

Jika penelitian ini dikaitkan dengan model komunikasi SMCR menurut model Berlo, sumber/source dipengaruhi oleh faktor-faktor: keterampilan komunikasi, sikap, pengetahuan, sistem sosial, dan budaya. Sumber merupakan suatu komponen terpenting dalam proses komunikasi, karena jika tidak ada sumber pesan yang ingin dikomunikasikan tidak ada. Sebuah sumber harus memiliki keterampilan komunikasi, karena keterampilan komunikasi merupakan keterampilan utama yang harus dimiliki oleh sumber untuk mampu membina hubungan yang sehat dimana saja, termasuk dalam bermedia sosial menggunakan Bigo Live, ketika berkomunikasi pada penonton otomatis penonton dapat menerjemahkan sikap yang diberikan baik atau buruk.

Dalam berkomunikasi di Bigo Live, sumber dan penerima pesan harus memiliki pengetahuan bagaimana cara berkomunikasi melalui Bigo Live dan pesan yang disampaikan oleh sumber akan diterjemah dengan mudah oleh penerima pesan. Segala aktivitas yang terjadi saat siaran live video merupakan bentuk sistem sosial karena segala tindakan sosial dapat dilakukan di Bigo Live seperti berinteraksi melalui fitur komentar dan video call secara real time. Sistem sosial yang dilakukan oleh penyiar dan penonton Bigo Live akan memunculkan budaya yang baru ke depannya karena budaya bermedia sosial akan semakin marak, semakin menarik dan berkembang. Jika dihubungkan dengan variabel X2 yaitu kepuasan diri, maka pada sumber dan penerima pesan menghasilkan adanya kepuasan dalam pemberian pesan yang disampaikan penyiar kepada penonton dan penyiar merasa puas karena dapat terhubung dan mendapatkan teman banyak dari Bigo Live.

Pesan dikembangkan berdasarkan elemen, struktur, isi, perlakuan, dan kode. Pesan yang disampaikan 
oleh penyiar Bigo Live kepada penontonnya dapat melalui elemen audiovisual secara langsung, dan penonton berupa chat secara real time. Bahkan, saat ini Bigo Live memiliki fitur video call secara real time atau langsung, sehingga struktur, isi, perlakuan dan kode pesan yang disampaikan lebih efisien dan efektif. Jika dihubungkan dengan variabel X2 yaitu kepuasan diri, maka para penyiar merasa puas karena pesan yang disampaikan oleh penyiar mendapatkan feedback pesan dari penontonnya sehingga penyiar merasa senang dan memiliki pengalaman yang indah, penyiar juga merasa puas karena mengetahui dan memahami informasi melalui pesan yang dibicarakan oleh penonton atau followersnya.

Khusus mengenai istilah Channel yang disingkat $\mathrm{C}$ pada rumus S-M-C-R itu yang berarti saluran atau media, komponen tersebut menurut Edwar Sappir mengandung dua pengertian, yakni primer dan sekunder. Sedangkan media sekunder adalah media yang berwujud, baik media masa, misalnya surat kabar, televisi atau radio, maupun media nirmassa, misalnya, surat, telepon, atau poster (Effendy, 2003, p.256). Dan dalam penelitian ini bahwa Media Sosial Bigo Live merupakan saluran atau channel yang digunakan oleh sumber atau source (Host Official Bigo Live) sebagai medium sekunder yang membawa pesan. Maka dari itu, peneliti ingin menguji apakah dengan media sosial Bigo Live sebagai saluran pembawa pesan yang digunakan oleh penyiar Bigo Live akan berpengaruh terhadap pembentukan aktualisasi diri para penyiar Bigo Live.

Salurannya (channel) berhubungan dengan panca indra: melihat, mendengar, menyentuh, membaui, dan merasai (mencicipi). Karena Bigo Live merupakan media sosial yang dapat dibilang mengikuti perkembangan teknologi saat ini, sehingga bentuk medianya berupa aplikasi yang dapat digunakan melalui smartphone yang sudah canggih dan dapat dilakukan dari jarak jauh. Maka dari itu, panca indra yang dapat digunakan dalam penggunaan media sosial tersebut hanyalah indra melihat dan mendengar. Karena elemen komunikasi yang diberikan melalui fitur aplikasi Bigo Live hanya berupa audiovisual dan komunikasi yang dilakukan berupa komunikasi dua arah (pengirim dan penerima informasi dapat menjalin komunikasi yang berkesinambungan melalui media yang sama seperti video call) dan komunikasi semi dua arah (pengirim dan penerima informasi berkomunikasi secara bergantian namun tetap berkesinambungan seperti menggunakan fitur chat). Jika dihubungkan dengan variabel $\mathrm{X} 2$ yaitu kepuasan diri, maka penyiar merasa puas bahwa status dirinya, kemampuan dirinya dan bakat yang dimilikinya dapat dilihat oleh penonton atau followers sehingga hal ini membuat penyiar sejenak melupakan masalah dan segala tekanan yang sedang dihadapi.

Jika dikaitkan dengan teori Uses and Gratification ini menyatakan bahwa orang secara efektif mencari media tertentu dan muatan (isi) tertentu untuk menghasilkan kepuasaan (atau hasil) tertentu (West dan Turner, 2008, p.101). Maka dari itu, sumber / source dalam penelitian ini secara efektif telah menentukan media atau channel yang akan dipilih yaitu media sosial Bigo Live melalui karakteristik dari sebuah media sosial tersebut. Sehingga para Host Official Bigo Live dapat merasakan kepuasan dari hasil penggunaan media sosial Bigo Live.

Teori Kegunaan dan Gratifikasi adalah perluasan dari teori kebutuhan dan motivasi (Maslow, 1970). Dalam teori kebutuhan dan motivasi, Abraham Maslow menyatakan bahwa orang secara aktif berusaha untuk memenuhi hierarki kebutuhannya. Setelah mereka memperoleh tujuan yang mereka cari pada satu tingkat hierarki, mereka dapat bergerak ke tahap berikutnya (West dan Turner, 2008, p.101). Berdasarkan teori tersebut bahwa setiap manusia mengalami tahap-tahap peningkatan kebutuhan atau pencapaian dalam kehidupannya. Kebutuhan tersebut meliputi kebutuhan fisiologis, kebutuhan keamanan dan keselamatan, kebutuhan sosial, kebutuhan akan penghargaan dan kebutuhan aktualisasi diri. Dari setiap kebutuhan tersebut peningkatan kebutuhan akan dipengaruhi oleh tingkat kepuasan diri yang telah didapatkan dari sebuah penggunaan media sosial Bigo Live. Sehingga para Host Official Bigo Live akan mendapat kebutuhan dan pencapaian tertinggi seorang manusia yaitu aktualisasi diri.

\section{SIMPULAN DAN SARAN}

Simpulan disusun berdasarkan hasil penelitian yang telah dilakukan dan didapatkan dari data-data melalui hasil penyebaran kuisioner kepada 91 responden yang telah ditentukan sebelumnya. Hasil dari data tersebut kemudian diolah agar dapat mudah dianalisis oleh peneliti dan pembaca pada umumnya. Berdasarkan hasil analisis peneliti dapat disimpulkan bahwa:

1. Ada pengaruh langsung dari penggunaan media sosial Bigo Live terhadap aktualisasi diri.

2. Ada pengaruh langsung dari kepuasan diri terhadap aktualisasi diri.

3. Gabungan dari kedua variabel memiliki pengaruh lebih besar terhadap aktualisasi diri daripada pengaruh langsung dari masing-masing variabel. 
4. Hubungan antara X1 (media sosial Bigo Live) dengan Y (aktualisasi diri) melemah atau hilang jika dimasukan variabel X2 (kepuasan diri).

\subsection{Saran Akademis}

1. Berdasarkan hasil penelitian, didapatkan hasil bahwa variabel X1 (Media sosial Bigo Live) dan X2 (Kepuasan diri) mempengaruhi Y (Aktualisasi diri) sebesar 69,3\% dan sisanya 30,7\% dipengaruhi oleh faktor-faktor lain yang tidak diteliti dalam model ini. Dengan demikian, dapat dilakukan penelitian atas pengaruh terhadap aktualisasi diri dengan mencari faktor-faktor lain.

2. Berdasarkan hasil penelitian, bahwa variabel X1 (Media sosial Bigo Live) tidak berpengaruh atau melemah apabila dimasukkan variabel X2 (Kepuasan diri). Dengan demikian, dapat dilakukan penelitian serupa dengan mencari variabel X2 dengan faktor-faktor lain yang mengakibatkan pengaruh lebih besar X1 terhadap Y (Aktualisasi diri).

3. Berdasarkan data dan hasil penelitian disarankan utuk diadakan penelitian serupa untuk meneliti media lain selain media sosial Bigo live.

\subsection{Saran Praktis}

1. Bagi perusahaan Bigo Live Ltd untuk meningkatkan aktualisasi para Official Host Bigo Live, diperlukan program acara pengembangan bakat untuk para Official Host Bigo Live.

2. Media sosial Bigo Live dapat menjadi sarana para penyiar untuk mencari aktualisasi dirinya, seperti minat untuk menjadi penyiar, penyanyi, komedian, aktris maupun aktor. Maka dari itu lebih diperbaiki segala sistem keamanan di Bigo Live sehingga tidak disalahgunakan.

Bagi perusahaan Bigo Live Ltd sebaiknya meningkatkan sarana dari fitur-fitur Bigo Live menjadi lebih baik dan berguna untuk para penyiar terutama Official Host Bigo Live, dikarenakan jika penyiar merasa puas terhadap media sosial Bigo Live, maka akan timbul rasa kepercayaan dan kenyamanan untuk menggunakan Bigo Live terus menerus. Sehingga pengaruh kepada aktualisasi diri para penyiar akan timbul secara langsung.

\section{DAFTAR PUSTAKA}

Afrian, M, M. (2015, Agustus, 20). Adakah Media Komunikasi Secanggih "Live Streaming Show? Di peroleh dari website: http://tekno.kompas.
com/read/2015/08/20/11330017/Adakah.Media. Komunikasi.Secanggih.Live.Streaming.Show

Effendy, O.U. (2003). Ilmu, Teori Dan Filsafat Komunikasil. Bandung: PT. Citra Aditya Bakti.

Hambali, A dan Jaenudin, U. (2013). Psikologi kepribadian. Bandung: CV. Pustaka Setia.

Hatriani, J. (2016, Januari, 13). Pengguna Internet Indonesia Terbanyak Keempat di Asia. Diperoleh dari website:http://katadata.co.id/grafik/ 2016/01/13/indonesia-peringkat-4-penggunainternet-asia

Hersinta \& Soepomo, V. (2011). Communicare Journal of Communication Studies. Aktualisasi diri dalam mengkomunikasikan meaning of suffering pada ibu dengan anak penyandang autis. 5 (1), 6-7. Retrieved from file:///C:/Users/User/ Downloads/11-32-1-PB.pdf

Kriyantono, R. (2014).Teknik Praktis Riset Komunikasi. Jakarta: Kencana Prenada Media Group

Littlejohn, S. W. \& Foss, K. A. (2009). Teori Komunikasi (Theories of Human Communication) Edisi 9. Jakarta: Salemba Humanika

Manua, L. (2016, Desember, 7). Live, Medsos Berbasis Siaran Langsung Kian Digemari. Diperoleh dari website http://www.bagitu.com/2016/ 12/07/bigo-live-media-sosial-berbasispenyiaran-langsung-ini-kian-memikat-banyakpengguna-indonesia/

Mulyana, D. (2009). Ilmu Komunikasi Suatu Pengantar. Bandung: PT Remaja Rosdakarya

Officer BIGO Live Indonesia. (2016). Recruitment BIGO Live Indonesia. Jakarta: BIGO Live Indonesia

Pradiatiningtyas, D. (2016). Jurnal Khasanah Ilmu. Peran Instagram Dalam Menarik Minat Wisatawan Berkunjung Ke Objek Wisata Yogyakarta. 2 (7), 1-8. Retrieved from http://ejournal.bsi.ac. $\mathrm{id} /$ jurnal/index.php/khasanah/article/view/705

Prasetyo, B. dan Jannah, M, L. (2008). Metode Penelitian Kuantitatif. Jakarta: PT Raja Grafindo Persada

Rasul, J. (2008). Teknologi Dan Informasi 2. Diakses dari: https://books.google.co.id/books?id=sxDlmi TcWkYC\&pg=PR11\&dq=komunikasi+internet $\& \mathrm{hl}=\mathrm{id} \& s a=X \& v e d=0 a h U K E w i X s v P 8 q \_P A h$ WMRI8KHTKgDCoQ6AEIKDAA\#v=onepag e\&q=komunikasi\%20internet\&f=false

Rilisiana. (2016, Juli, 12). Hadir Di Indonesia - Bigo Live, A Live Video Streaming Social Network. Di peroleh dari website:http://www.rilisiana. com/hadir-di-indonesia-bigo-live-a-live-videostreaming-social-network/

Robbins, S.P., dan Coulter, M. (2010). Manajemen (Edisi Kesepuluh). Jakarta: Erlangga. 
Safko, L \& Brake D.K (2009). The Social Media Bible. New Jersey: Tactics, Tools, \& Strategies For Business Succes. New Jersey: John Wiley \& Sons, Inc.

Siregar, S. (2013). Metode Penelitian Kuantitatif: Dilengkapi Dengan Perbandingan Perhitungan Manual \& SPSS. Jakarta: Prenadamedia Group

Sugiyarto. (2016, Agustus, 27). Mengapa Wanita Rela Umbar Aurat Di Bigo Live Ternyata Ini Imbalannya. Di akses dari: http://www.tribunnews.com/lifestyle/2016/08/27/mengapawanita-rela-umbar-aurat-di-bigo-live-ternyataini-imbalannya

Sugiyono. (2012). Metode Penelitian Kombinasi (Mixed Methods). Bandung: Penerbit Alfabeta.

Sugiyono. (2013). Metode Penelitian Kuantitatif Kualitatif Dan $R \& D$. Bandung: Penerbit Alfabeta.

Telengkeng, H. (2014). Jurnal E-Komunikasi. Motif Penonton Perempuan Surabaya dalam Menon- ton Program Televisi "On The Spot" di Trans 72(3), 1-8. Retrived from http://id.portalgaruda. org/?ref=browse\&mod=viewarticle\&article $=35$ 8310

Thurlow, C., Lengel, L., \& Tomic, A. (2007). Computer Mediated Communication: Social Interaction and The Internet. London: SAGE Publication Ltd

Tjiptono, F. dan Chandra, G. (2005). Service, Quality, Satisfaction. Yogyakarta: Andi Offset

Windratie. (2015, Agustus 7). Selfie Di Media Sosial Mau Narsis Atau Eksis?. Di peroleh dari website: http://www.cnnindonesia.com/gayahidup/ 20150107115000-255-22916/selfie-di-mediasosial-mau-narsis-atau-eksis/

West, R dan Turner, L.H, (2008). Pengantar Teori Komunikasi Analisis dan Aplikasi Edisi 3, Jakarta: Salemba Humanika. 